\title{
Emotional distress among caregivers of patients with epilepsy in Katsina State, Northern Nigeria
}

\author{
AJ Yusuf', FT Nuhu², Vo Olisah' \\ 'Department of Psychiatry, Ahmadu Bello University Teaching Hospital, Shika-Zaria, Nigeria \\ 2Federal Neuropsychiatry Hospital, Barnawa, Kaduna, Nigeria
}

\begin{abstract}
Objective: Caregivers of patients with epilepsy experience considerable emotional distress. The study aimed to assess the magnitude of the problem in a developing country. Method: A total 166 patients-caregivers were enrolled for the study. They were interviewed using a socio-demographic data collecting sheet and the Hospital Anxiety-Depression Scale (HADS). Data obtained were analysed using Statistical Package for Social Sciences Windows version 13. All statistical tests were carried out at a 5\% level of probability. Results: The mean age of the caregivers was $45.44 \pm 6.67$ years. Emotional distress was found among $109(65.7 \%)$ of the caregivers. This is was significantly associated with male gender of both care giver and patient as well as residing in a rural area. Conclusion: The study demonstrated a high level of emotional distress associated with caring for patients with epilepsy, which is comparable to other studies carried out in other parts of the world.
\end{abstract}

Key words: Epilepsy; Caregivers; Emotions; Nigeria

Received: 01-14-2011

Accepted: 28-11-201 1

doi: http://dx.doi.org/10.4314/ajpsy.v16il.7

\section{Introduction}

Epilepsy is a treatable but potentially devastating condition in low resource areas where access to treatment is not readily available. It has been estimated that about 3-4 millions Africans suffer from epilepsy with $80 \%$ of them having no access to modern medical facilities. ${ }^{1,2}$ The disease is associated with stigma which is not only limited to the patient but also includes other family members. ${ }^{3,4}$ Caregivers are people who take care of other adults, often parents or spouses, or children with special medical needs or disability. 5 They are usually unpaid family members or friends of the person with the disability or illness., ${ }^{5,6}$ Emotional distress among caregivers has been defined as mood disturbances like anxiety, depression, feeling of loneliness, isolation, fearfulness and being easily bothered - all arising from providing care for a sick relative. ${ }^{7}$ Family caregivers of patient with chronic illness,

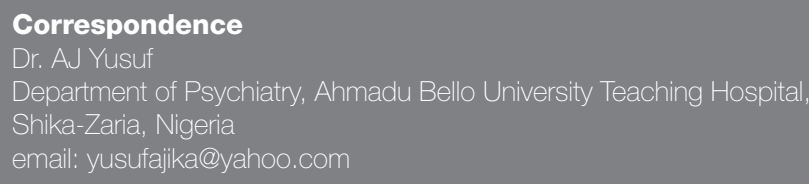

like epilepsy, have often been described as forgotten patients and it was suggested that a caregiver's symptoms such as mood swings, fatigue, headaches, joint and muscle pains, marital and family conflicts, and financial problems may be a reflection of caregiver stress in looking after a sick relative. ${ }^{8}$ Reports of studies carried out in various parts of the world have indicated that caring for patients with epilepsy is associated with emotional distress, burden, impaired quality of life in caregivers and poor outcome of the disease in both patients and caregivers. ${ }^{8-11}$ These can be alleviated with provision of psycho-education, accessible and affordable modern health care facilities to both patients with epilepsy and caregivers. ${ }^{9}$ In Nigeria and other sub-Saharan African countries modern health services are often centralized and difficult to access by the majority of sufferers that require such services. ${ }^{12-14}$ This is further complicated by the near absence of expert personnel to handle cases of epilepsy. ${ }^{14}$

This study is an attempt to identify the magnitude and factors associated with emotional distress among care givers of patients with epilepsy in a poorly resourced environment. In view of the dearth of literature or studies focused on caregivers of patients with epilepsy, this study also provided an insight into the problems facing the "hidden patients" 


\section{Method}

Site

The study was conducted at the Katsina state Psychiatry Hospital. The state is located within the Savannah region of North Western Nigeria about 600 kilometers from the Federal Capital Territory Abuja. Katsina state is one of the 36 federating units of Nigeria and has a population of about 4 million people based on the National population census conducted in 1991.15 The main economic activities in the state are agriculture and small scale trading. The hospital is the only mental health facility in the state. It offers services to patients with mental illness and neurological diseases like epilepsy. As in other developing countries a large proportion of patients with epilepsy are being managed by a psychiatrist in the absence of a neurologist. ${ }^{14}$ It also receives referral from the neighbouring states and the Niger Republic. The hospital is the only mental health facility in the state. It offers both inpatient and out -patient services to patients with mental illness and neurological diseases like epilepsy.

\section{Sample}

The sample comprised caregivers of consecutive attendees of the clinic receiving treatment for epilepsy between December 2009 to April 2010. The inclusion criteria were: clinical diagnosis of epilepsy, receiving treatment for at least 1 year and living together with the caregiver who is involved in monitoring adherence to medications and attending follow up clinic with the patient in the last 1 year. Caregivers with a previous history of mental illness were excluded from the study. This was ascertained by asking the caregivers of the need to see psychiatrist for treatment. Caregivers of patients with co-morbid mental retardation were also excluded from the study

\section{Procedure}

The respondents were interviewed using the following instruments:

i. Socio-demographic data collection sheet: this was designed for the purpose of this study. It elicited information such as age, gender, income, duration of illness and other related data.

ii. Hospital Anxiety Depression Scale (HADS). This was developed to assess anxiety and depressive symptoms among non psychiatric patients in the hospital. ${ }^{16}$ The instrument had been validated in many countries including Nigeria. ${ }^{17-19}$ HADS has also been found useful in the assessment of psychiatric morbidity in the community. The instrument consists of seven items each for depression and anxiety. Scales are rated on a four point scale ranging from 0-3. A cut of point of 8 and above in either anxiety of depressive subscale indicates depression or anxiety. ${ }^{19}$ The respondents in this study were categorised into two groups based on their scores in the HADS. Respondents with score of 8 and above in either or both of the HADS sub-scales were considered to have emotional distress. While those with scores of less than 8 in both subscales were considered to be normal.

The instruments were translated into the local language of the area (Hausa) using a back translation method to confirm accuracy. All the respondents were interviewed by one author (AJY) in the local language.

\section{Ethics}

Ethical approval for the study was granted by the Katsina state Health Services Management Board. An informed writtenconsent was obtained from each of the respondents before conducting the interview. The consent form was read out to those who could not read in local language (Hausa). After which they were asked to thumb print the consent form.

\section{Statistical analysis}

The data obtained from the study was analysed using Statistical Package for Social Sciences version 13 for Windows. Descriptive statistic was calculated for all continuous variables. Chi square test and student " $t$ " test were used to test for association. All statistical tests were carried out at 5\% level of probability.

\section{Results}

A total of 166 caregivers participated in the study. All the caregivers that fulfilled the inclusion criteria agreed to participate in the study. The mean age of the participants was $45.44 \pm 6.67$ years. The mean age of the female caregivers was $44.04 \pm 7.54$, while that of male caregivers was $46.59 \pm 5.62$. There was no significant difference between the male and female caregivers $(t=2.43, p=0.17)$. The mean age of the male patients was $18.41 \pm 6.12$, while that of the female patients was $19.71 \pm 7.53$ years. There was also no significant difference in the ages of the patients $(t=1.21, p=0.23)$. Other socio-demographic characteristics of the patients are shown in Table I. The mean

Table I: Socio-demographic characteristics of the caregivers

\begin{tabular}{|c|c|c|}
\hline Variable & Frequency (N) & Percentage (\%) \\
\hline $\begin{array}{l}\text { Gender } \\
\text { Male } \\
\text { Female }\end{array}$ & $\begin{array}{l}75 \\
91\end{array}$ & $\begin{array}{l}45.20 \\
54.80\end{array}$ \\
\hline $\begin{array}{l}\text { Formal education } \\
\text { Yes } \\
\text { No }\end{array}$ & $\begin{array}{l}21 \\
145\end{array}$ & $\begin{array}{l}12.70 \\
87.30\end{array}$ \\
\hline $\begin{array}{l}\text { Pt gender } \\
\text { Male } \\
\text { Female }\end{array}$ & $\begin{array}{l}88 \\
78\end{array}$ & $\begin{array}{l}53.0 \\
47.0\end{array}$ \\
\hline $\begin{array}{l}\text { Duration of illness } \\
>2 \text { years } \\
\leq 2 \text { years }\end{array}$ & $\begin{array}{l}75 \\
91\end{array}$ & $\begin{array}{l}45.2 \\
54.8\end{array}$ \\
\hline $\begin{array}{l}\text { Family Size } \\
<5 \\
\geq 5\end{array}$ & $\begin{array}{l}38 \\
128\end{array}$ & $\begin{array}{l}22.90 \\
77.10\end{array}$ \\
\hline $\begin{array}{l}\text { Financial assistance } \\
\text { Yes } \\
\text { No }\end{array}$ & $\begin{array}{l}21 \\
145\end{array}$ & $\begin{array}{l}12.70 \\
87.30\end{array}$ \\
\hline $\begin{array}{l}\text { Relationship } \\
\text { Parents } \\
\text { Siblings }\end{array}$ & $\begin{array}{l}141 \\
25\end{array}$ & $\begin{array}{l}84.90 \\
15.10\end{array}$ \\
\hline $\begin{array}{l}\text { Place of Residence } \\
\text { Rural } \\
\text { Urban }\end{array}$ & $\begin{array}{l}100 \\
66\end{array}$ & $\begin{array}{l}60.20 \\
39.80\end{array}$ \\
\hline
\end{tabular}


anxiety and depression scores were 6.98 \pm 2.76 and $6.19 \pm 2.38$ respectively. The relationship between the HADS scores and socio-demographic characteristics of the caregivers are shown in Table II. Emotional distress based on the HADS scores was found among 109(65.7\%) of the caregivers. This consisted of anxiety ( $\mathrm{n}=64 ; 38.6 \%)$, depression ( $\mathrm{n}=31 ; 18.7 \%)$ and co morbid anxietydepression ( $\mathrm{n}=17 ; 10.2 \%$ ) amongst caregivers respectively. The relationship between emotional distress and sociodemographic characteristics of the respondents are shown in Table III.

\section{Discussion}

The preponderance of parents among the caregivers can be explained by the relatively young age of the patients. Females constituted the majority of the caregivers in this study. This is in keeping with the tradition of the area where female relatives constitute the majority of caregivers. A similar observation was made by an earlier study in this environment involving patient-caregiver pairs. ${ }^{6}$ Emotional distress was found to be very high among these caregivers. This is similar to the findings of other studies among caregivers of patients with epilepsy in other part of the world. ${ }^{8-11}$ Emotional distress in this study is significantly associated with male gender, providing care for male patients, siblings, and residing in a rural area. The association between male gender of the care giver and emotional distress might be because providing care for a relative with chronic medical illness in this environment is usually done by females. Another possible explanation is the additional burden of providing for the needs of other members of the family by the male caregivers. In Sub Saharan Africa males are usually the breadwinners of their families. Residing in a rural area limits access to medical facilities in developing countries like Nigeria. ${ }^{12-14}$ This might explain the high level of emotional distress observed among caregivers from rural areas in this study. In this study caring for male patients was significantly associated with emotional distress among the caregivers. This might be explained by the culture of the area that placed high premium on male children. As such caregivers of the male patients are more likely to experience emotional distress. The study also observed high levels of emotional distress among siblings that are caregivers and those receiving financial assistance from a non family source. A likely explanation for the high level of emotional distress among siblings is that caregivers shoulder additional burdens caring and providing for their immediate nuclear family in the face of general economic hardship in the country. Another possible explanation is that the sibling caregivers were relatively young and as such could not effectively cope with the role bestowed on them. Caregivers receiving

\section{Table II: Relationship between HADS scores and socio-demographic characteristic of caregivers}

\begin{tabular}{|c|c|c|c|c|}
\hline Variable & Mean anxiety scores & Statistics & Mean depression score & Statistics \\
\hline $\begin{array}{l}\text { Gender } \\
\text { Male } \\
\text { Female }\end{array}$ & $\begin{array}{l}7.56 \pm 2.98 \\
6.50 \pm 2.47\end{array}$ & $t=2.45, p=0.016$ & $\begin{array}{l}6.44 \pm 1.25 \\
6.10 \pm 3.00\end{array}$ & $t=1.18, p=0.238$ \\
\hline $\begin{array}{l}\text { Formal education } \\
\text { Yes } \\
\text { No }\end{array}$ & $\begin{array}{l}6.86 \pm 3.39 \\
7.07 \pm 2.15\end{array}$ & $t=.49, p=0.62$ & $\begin{array}{l}6.18 \pm 1.53 \\
6.21 \pm 2.89\end{array}$ & $t=.16, p=0.92$ \\
\hline $\begin{array}{l}\text { Pt gender } \\
\text { Male } \\
\text { Female }\end{array}$ & $\begin{array}{l}6.66 \pm 3.41 \\
7.35 \pm 1.70\end{array}$ & $t=1.61, p=0.13$ & $\begin{array}{l}5.83 \pm 2.23 \\
6.61 \pm 2.49\end{array}$ & $t=2.13, p=0.035$ \\
\hline $\begin{array}{l}\text { Duration of illness } \\
>2 \text { years } \\
\leq 2 \text { years }\end{array}$ & $\begin{array}{l}6.89 \pm 2.73 \\
7.15 \pm 2.80\end{array}$ & $t=.69, p=0.13$ & $\begin{array}{l}6.16 \pm 2.27 \\
6.23 \pm 2.09\end{array}$ & $t=.19, p=0.85$ \\
\hline $\begin{array}{l}\text { Family Size } \\
<5 \\
\geq 5\end{array}$ & $\begin{array}{l}7.58 \pm 3.56 \\
6.80 \pm 4.50\end{array}$ & $t=1.53, p=0.13$ & $\begin{array}{l}8.18 \pm 2.12 \\
5.16 \pm 2.13\end{array}$ & $t=6.54, p=0.001$ \\
\hline $\begin{array}{l}\text { Financial assistance } \\
\text { Yes } \\
\text { No }\end{array}$ & $\begin{array}{l}8.47 \pm 1.51 \\
6.76 \pm 2.88\end{array}$ & $t=2.70, p=0.008$ & $\begin{array}{l}5.00 \pm 0.00 \\
6.37 \pm 2.50\end{array}$ & $t=2.50, p=0.013$ \\
\hline $\begin{array}{l}\text { Relationship } \\
\text { Parents } \\
\text { Siblings }\end{array}$ & $\begin{array}{l}6.58 \pm 2.63 \\
9.20 \pm 2.45\end{array}$ & $t=4.86, p=0.001$ & $\begin{array}{l}6.23 \pm 2.54 \\
6.00 \pm 1.12\end{array}$ & $\mathrm{t}=.45, \mathrm{p}=0.46$ \\
\hline $\begin{array}{l}\text { Place of Residence } \\
\text { Rural } \\
\text { Urban }\end{array}$ & $\begin{array}{l}8.00 \pm 2.45 \\
5.44 \pm 2.47\end{array}$ & $\mathrm{t}=6.55, \mathrm{p}=0001$ & $\begin{array}{l}6.81 \pm 2.38 \\
5.27 \pm 2.09\end{array}$ & $t=4.27, p=0.001$ \\
\hline
\end{tabular}




\begin{tabular}{|l|l|l|l|}
\hline \multicolumn{4}{|l|}{ Table III . Relationship between emotional distress and socio- } \\
demographic characteristics of the caregivers
\end{tabular}

financial assistance from non-family sources are more likely to be from lower socio-economic groups and might experience greater financial strain.

The findings of this study alerts professionals providing medical care to patients with chronic medical illnesses like epilepsy to pay attention to the needs of caregivers, especially in relation to emotional problems. The study also shows the need to provide assistance to caregivers in terms of financial costs of providing care to these patients. This could be in form of free medication and consultation for the treatment of epilepsy.

\section{Limitations}

This was cross-sectional study utilizing a screening instrument to for depression and anxiety to assess emotional distress. However, the instrument has been widely used to demonstrate emotional distress among various groups of subjects. The study is hospital based and access to hospital care is not easy in low resourced areas. As such the findings of this study might not necessarily reflect the situation in the wider community. Seizure frequency and types of seizures were also not taking into consideration in this study insofar as a care giver looking after a patient with daily generalised seizures is far more likely to be distressed than one taking care of a patient with well controlled seizures or partial seizures.

\section{Conclusion}

The study found high levels of emotional distress among caregivers, which is comparable to studies carried out in other parts of the world. The findings of this study show the need for the provision of accessible, affordable care for patients with epilepsy and support for the family caregivers.

\section{References}

1. Ahmad K. WHO to improve management of epilepsy in Africa. Lancet 2000; 355:1706.

2. Slikkerveer LJ. Rural health development in Ethiopia: problems of utilization of traditional healers. Soc Sci Med 1982;1 6:1859-72.

3. Birbeck GL, Chomba E, Atadzhanov, M, Mbewe E, Haworth A. Women's Experiences Living with Epilepsy in Zambia. Am J Trop Med Hyg 2008; 79: 168-172.

4. Baskind R, Birbeck GL. Epilepsy-associated stigma in subSaharan Africa: the social landscape of a disease. Epilepsy Behav 2005; 7:68-73.

5. Given B, Wyatt G, Given C, Gift A, Sherwood P, DeVoss D et al (2005) Burden and depression among caregivers of patients at end of life. Oncol Nurs Forum20005; 31:1 105-111.

6. Baiyewu O, Smith-Gamble V, Akinbiyi A, et al. Behavioural and Caregiver reaction as measured by neuropsychiatry inventory in Nigeria. Int Psychogeriat 2003; 15: 399-409.

7. Medalie JH. The caregiver as hidden patient: Theory and research on health care triads. J Health Soc Behav 1994; 35:1-12.

8. Lee MM, Lee TM, Ng PK, Hung TA, Au AM, Wang VC. Psychosocial wellbeing of people with epilepsy in Hong Kong. Epilepsy Behav 2002; 3:147-157.

9. Westphal-Gutti AC, Alonso WB, Migliorini RC et al. Quality of life and burden in caregivers of patients with epilepsy. J Neuro Sci Nur 2007; 39:354-369.

10. Thompson PJ, Upton D. Impact of chronic epilepsy on the family. Seizure 1992; 1:43-48.

11. Li Y, Ji CY, Qin J, Zhang ZX. Parental anxiety and quality of life of epileptic children. Biomed Environ Sci 2008, 21:228-232.

12. Ayorinde O, Gureje O, Lawal R. Psychiatric research in Nigeria: bridging tradition and modernisation. Br J Psychiatry 2004; 184: 536-538.

13. Birbeck G, Munsat T. Neurologic services in sub-Saharan Africa: a case study of Zambian primary healthcare workers. J Neurol Serv 2002; 200:75-78.

14. World Health Organistaion. Atlas of Neurology, 2004.

15. National Population Commission. Final population figures 1992; Lagos Niigeria.

16. Zigmond AS, Snaith RP. The Hospital Anxiety and Depression Scale. Act Psychiatrica Scand 1983;67 : 361-370.

17. Spinhoven P, Ormel J, Sloeker PP, Speckens AE, Van Hermert AM. A validation of the Hospital Anxiety and Depression Scale (HADS) in different group of Dutch subjects. Psychol Med 1997; 27:363-370.

18. Harrero MJ, Blanch J, Peri JM, DePablo J, Pintor, L Bulbena A .A validation study of the Hospital Anxiety and Depression Scale (HADS) in a Spanish population. Gen Hosp Psychiatry 2003; 25: 277-283.

19. Abiodun OA. A validity study of Hospital Anxiety and Depression Scale in general hospital units and community sample in Nigeria. BrJ Psychiatry 1994; 165: 669-672. 